\title{
Przyslowia internacjonalne a wielojęzyczność w dydaktyce
}

\section{International proverbs and the multilingual didactic methods}

Joanna Woźniak

(Poznań)

\begin{abstract}
This article deals with the concept of introducing international proverbs to the foreign language lesson. International proverbs can be a good way to improve language skills in at least two foreign languages with less effort by using the analogy between the languages. What is more the experience that the student gains by learning the first foreign language, can be used while learning the second and the next one. Moreover international proverbs, in regard of the European policy supporting multilingualism among the European citizens, help to achieve this goal.
\end{abstract}

Tematem niniejszego artykułu są przysłowia internacjonalne w dydaktyce ukazane w kontekście wielojęzyczności. W artykule tym, w celu zobrazowania określonych zjawisk językowych, zostaną wykorzystane przykłady przysłów internacjonalnych w języku polskim, angielskim i niemieckim, choć zaznaczyć należy, iż poniższe wnioski i spostrzeżenia można przenieść również na inne kombinacje językowe. Artykuł obejmuje krótki zarys problematyki wielojęzyczności i jej istoty dla integracji europejskiej. Następnie omówione zostaną konsekwencje wspierania wielojęzyczności w dydaktyce języków obcych. W dalszej części zwrócę uwagę na istotę 
przysłów internacjonalnych oraz ich wplyw na rozwój kompetencji interkulturowej i wielojęzycznej.

\section{Wielojęzyczność a polityka językowa Europy}

Truizmem jest stwierdzenie, iż w dobie integracji europejskiej znajomość języków obcych zyskuje na znaczeniu. Umiejętność poshugiwania się zaledwie jednym językiem obcym często nie spelnia wymogów pracodawców, a także może stanowić przeszkodę w poznawaniu walorów kulturowych świata. $Z$ tego powodu europejskie i krajowe instytucje oświatowe stawiają sobie za cel rozwój kompetencji wielojęzyczności u swoich obywateli. Przez wielojęzyczność rozumie się, najogólniej rzecz biorąc, umiejętność mówienia wieloma lub kilkoma językami (por. PWN pod haslem: wielojęzyczność). Niemiecki badacz Edmondson (2004: 39) definiuje wielojęzyczność jako umiejętność komunikowania się w przynajmniej trzech językach. Według Komisji Europejskiej - coraz usilniej wspierającej rozwój wielojęzyczności w Europie - celem wielojęzyczności jest umiejętność porozumiewania się tak, aby móc realizować swój potencjal intelektualny i optymalnie wykorzystywać możliwości, jakie oferuje nowoczesna i innowacyjna Unia Europejska (por. Komisja Wspólnot Europejskich 2008: 3).

Wielojęzyczność - przez lata niedoceniana i krytykowana w latach dziewięćdziesiatych ubieglego wieku, a w szczególności w ostatniej jego dekadzie, stała się zjawiskiem pożądanym z uwagi na ogrom zalet, które ze sobą niesie. „Skuteczna polityka wielojęzyczności może zwiększyć perspektywy życiowe obywateli, poprawić ich szanse na rynku pracy, ułatwić dostęp do uslug i należnych im praw. Może ona również przyczynić się do solidarności, poprzez wzmocniony dialog międzykulturowy i spójność spoleczna.." (Komisja Wspólnot Europejskich 2008: 2). Dlatego też Komisja Europejska w 2003 roku zaapelowala do państw czlonkowskich i wprowadzila obowiązek nauczania co najmniej dwóch języków obcych (por. Komisja Europejska 1995: 47), a także podkreślila istotę możliwie 
jak najwcześniejszej implementacji języków obcych w szkolach, a nawet przedszkolach (Komisja Europejska 1995: 49).

Istotną rolę w polityce wielojęzyczności odgrywa wybór języków, a także kolejność ich nauczania. Wedlug Europejskiego Urzędu Statystycznego Eurostat w 2006 roku niemal we wszystkich krajach Unii Europejskiej pierwszym językiem obcym nauczanym w szkolach średnich byl angielski. Ponadto angielski jako oficjalny język biznesu nie tylko w Europie, ale w skali calego świata, coraz częściej w wielu częściach Europy traktowany jest raczej jako podstawowa umiejętność, a nie jako język obcy. Więcej watpliwości rodzi wybór kolejnego języka obcego. Choć często postuluje się konieczność nauki języka państwa ościennego, to rynek pracy oraz indywidualne upodobania w znacznie większym stopniu determinuja ten wybór. Z danych Forum Biznesu ds. Wielojęzyczności wynika, iż największym zainteresowaniem na rynku pracy Unii Europejskiej cieszą się, oprócz języka angielskiego, język niemiecki, francuski i rosyjski.

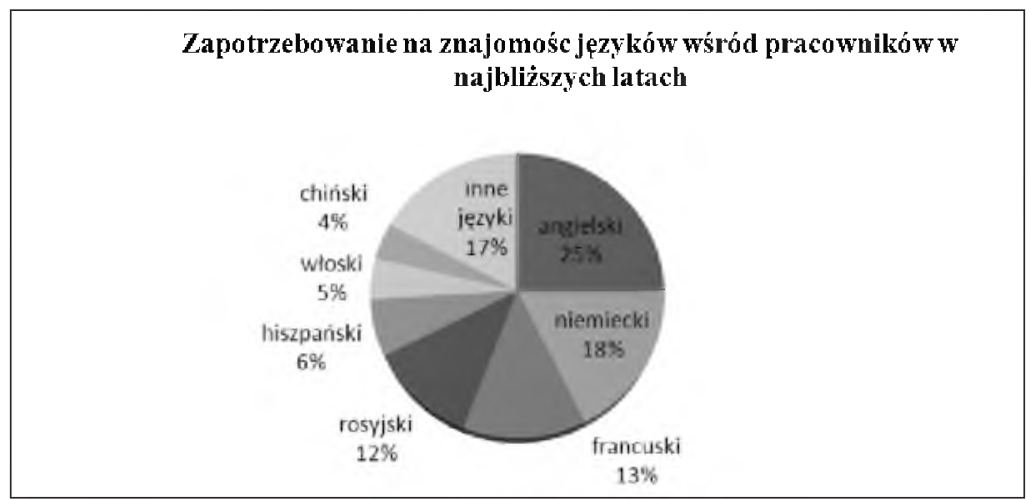

Źródło: Forum Biznesu ds. Wielojęzyczności

Droga do wielojęzyczności zarówno jednostki, jak i całego spoleczeństwa przebiega w sposób niejednolity. Często uwarunkowana jest sytuacją geospoleczną tejże jednostki lub calego spoleczeństwa. 
Wielojęzycznym można stać się w naturalny sposób, dorastając w środowisku multilingwalnym. Dotyczy to najczęściej grup ludności żyjących na terenach przygranicznych lub w państwach wielonarodowościowych (por. Edmondson 2004: 39). Drugi sposób rozwijania kompetencji wielojęzyczności to systematyczna i możliwie jak najwcześniejsza nauka języków obcych w szkołach (por. Edmondson 2004: 39), co w sytuacji Polski zdaje się mieć większe znaczenie. Sposobów na rozwijanie kompetencji wielojęzyczności jest wiele, choć te najbardziej efektywne wykorzystuja doświadczenie uczacych się zdobyte we wcześniejszych etapach nauki języka ojczystego i języków obcych i opierają się o zasady pozytywnego transferu lingwistycznego między tymi językami. I tak jednym ze sposobów jest integrowanie internacjonalnych elementów leksykalnych, w szczególności internacjonalizmów, które ukazują podobieństwa między tym, co już poznane a tym, co wciąż nowe, przez co wzmacniają motywację do dalszej nauki, np.:

pol.: infrormacja

ang.: information

niem.: die Information

Implementacja wielojęzyczności w kontekście nauki języków obcych nie powinna jednak ograniczać się jedynie do przyswajania struktur leksykalnych i gramatycznych, czy do umiejętności poprawnego poshugiwania się danym językiem. Edukacja wielojęzyczna, to edukacja interkulturowa. Dlatego istotne jest, by na zajęciach uwzględniać również treści interkulturowe, obejmujące wiedzę z zakresu kultury, tradycji, zwyczajów danego państwa. Stąd też coraz częściej podkreśla się rolę zastosowania frazeologii internacjonalnej na zajęciach języków obcych. W literaturze poruszone zostały już funkcje internacjonalizmów frazeologicznych w nauce języków obcych (por. Maćkiewicz 1988, Basaj, Schatte 2006), czyli frazeologizmów o podobnej formie i treści, czy też jak pisze Maćkiewicz (1992: 147) międzynarodowych analogii frazeologicznych, $\mathrm{np}$ : 
pol.: być czyjaśs prawa reka

ang.: to be sb 's right hand

niem.: jds rehte Hand sein

Niedoceniony pozostaje jak dotąd wkład przysłów internacjonalnych w rozwój wielojęzyczności, które z racji swojej analogii do internacjonalizmów frazeologicznych będę nazywać w moim referacie internacjonalizmami paremiologicznymi, $\mathrm{np}$.:

pol.: Nie ma róży bez kolców.

ang.: No rose without thorns.

niem.: Keine Rosen ohne Dornen.

\section{Przyslowia w dydaktyce}

Korzyści wynikające ze stosowania przysłów na zajęciach języków obcych sa nieocenione. Przyslowia jako madrość narodów sa bogatym źródłem treści interkulturowych. Są to ogólnie znane sekwencje o utrwalonej strukturze, wyrażające regułę lub mądrość życiową w krótkiej i zwięzlej formie (por. Mieder/Röhrich 1977: 2). Ponadto o przysłowiach można powiedzieć, iż są zakorzenione w tradycji ludowej, ogólnie uznawane i powtarzane, przez co latwo je zapamiętać (por. Umorova 2005: 24). Mają najczęściej formę pelnych zdań, moga jednak występować również w formie równoważników zdań. Ich charakterystyczną cechąjest strukturalna i leksykalna stabilność, która sprawia, iż kolejność i forma ich składników są z góry określone, a jakakolwiek zmiana w tej strukturze stawia jej przyslowiowy charakter pod znakiem zapytania. Przyslowia bardzo często bywają idiomatyczne, w następstwie czego ich znaczenie rozpatrywane jest w dwóch wymiarach: doslownym, czyli analitycznym i przenośnym, czyli syntetycznym (por. Permjakov 1979: 12ff.) np.:

Po pracy mity odpoczynek. After the work is done, repose is sweet./ Nach getaner Arbeit ist gut ruhn. - przyslowie analityczne; rozumiane „wprost” 
Kto chce z wilkami przestawać, musi wyć jak one. Who keeps company with a wolf, learns to howl./Bei Wölfen und Eulen lernt man heulen. - przyslowie syntetyczne; znaczenie przenośne

Kolejną cechą przyslów jest ich obrazowość. Opisują one rzeczywistość - tę abstrakcyjna, jak i tę namacalna - poprzez obrazy, które towarzyszajjej w życiu codziennym. Stąd częstymi motywami w przyslowiach są elementy natury czy rzeczy z bezpośredniego środowiska czlowieka, np.:

Bei Wolfen und Eulen lernt man heulen.

Kto chce z wilkami przestawać, musi wyć jak one.

Who keeps company with a wolf, learns to howl.

Do cech konstytutywnych przysłów zaliczyć należy również ich reproduktywność. Przyslowia są kombinacja znaków zakotwiczonych w pamięci jako calość, co sprawia, iż są one przywolywane z pamięci jak elementy leksykalne, nie są natomiast, tak jak zwykle zdania, każdorazowo formulowane i budowane od nowa (por. Burger 1998: 100). Nie wymagają również dopasowania pod względem strukturalnym i gramatycznym do kontekstu, w którym są używane (por. Burger 1998: 100).

Swoje pochodzenie przyslowia zawdzięczają w dużej mierze starożytnemu piśmiennictwu, przede wszystkim Biblii oraz greckim i rzymskim filozofom, pisarzom i poetom, ale także lacinie średniowiecznej i literaturze XVI i XVII wieku (por. Mieder/Röhrich 1977: 26). Należy jednakże podkreślić, iż piśmiennictwo antyczne, średniowieczne czy też szesnasto- i siedemnastowieczne jest jedynie pierwszym pisemnym dowodem na istnienie danego przysłowia. Ich pochodzenie jest bardzo często dużo starsze i wywodzi się glównie z ustnych przekazów ludowych. Zanim nabraly one ostatecznego ksztaltu ulegaly licznym modyfikacjom, jak na przyklad angielskie przysłowie (por. Mieder 2004: 9): 
It is good to be wise before the mischief (1584)

After the business is over, every one is wise. (1666)

It is easy to be wise after the event. (1900).

Poza wymienionymi wyżej ogólnoeuropejskimi źródłami pochodzenia przyslów zwrócić należy uwagę na ogromną rolę przysłów zapożyczonych, które wskutek thumaczeń z innych języków na stale zagościly w kulturze danego spoleczeństwa. Zapożyczenia przyslów z innych języków świadczą o istniejacych podobieństwach między narodami w postrzeganiu świata, w obowiązujących normach, czy regulach wspólżycia spolecznego. W następstwie wiernego tlumaczenia przyslów antycznych, jak i tych późniejszych powstaly przysłowia internacjonalne, czy też jak nazwalam je na wstępie internacjonalizmy paremiologiczne.

\section{Internacjonalizmy paremiologiczne a nauka języków obcych}

Internationalizmy paremiologiczne to przysłowia mające swoje analogiczne odpowiedniki w przynajmniej trzech różnych językach, przy czym języki te muszą należeć do przynajmniej dwóch różnych grup językowych (por. Lipczuk 1992: 135). Należy podkreślić, iż internacjonalizmy paremiologiczne można wyselekcjonować niemalże we wszystkich językach europejskich i znacznej części języków świata. Pokrywają się one zarówno pod względem logicznosemantycznym, jak i pod względem formalnym (por. Bartoszewicz 1998: 12). Internacjonalizmy paremiologiczne, podobnie jak internacjonalizmy frazeologiczne, przekazuja podobne treści, stosuja to samo slownictwo i podobne struktury syntaktyczne. Tematycznie poruszają najczęściej podobną problematykę życia spolecznego, stosunków międzyludzkich, zjawisk fizycznych, świata przyrody, obowiązujących norm i innych zjawisk, np.: 
Male dzieci-maly klopot; duże dzieci - duzy klopot. Little children, little sorrow, big children, big sorrow. Kleine Kinder-kleine Sorgen; große Kinder-große Sorgen.

Jedna parszywa owca cale stado zarazi. One scabbed sheep will mar a flock. / Ein raudiges Schaf steckt die ganze Herde an.

Nikt nie może być sędzia we wlasnej sprawie. No man should be judge in his own case. / Niemand kann Richter in eigener Sache sein.

życie spoleczne

stosunki

międzyludzkie

obowiązujące

normy

W kontekście nauczania języków obcych internacjonalizmy paremiologiczne, stanowią doskonaly material do pracy na lekcjach. Mimo, iż istnieją poglądy marginalizujące pozycję przysłów w języku i negujące ich istotę w nauczaniu języków obcych, należy stwierdzić, iż przysłowia są wszechobecne zarówno w języku potocznym, jak i w języku mediów, choć często występują w formie zmodyfikowanej (por. Zenderowska-Korpus 2002: 282) jako tzw. antyprzysłowia, które bazująna pierwotnym brzmieniu i pierwotnej strukturze przyslowia, ale zmieniaja je w celu nadania wypowiedzi żartobliwego tonu lub celowe zwrócenie uwagi na pewien aspekt, np.:
Mowa jest srebrem, a milczenie złotem.
Mowa jest srebrem,
Don't bite the hand that feeds you.

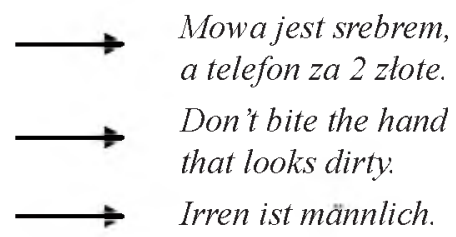
Irren ist menschlich. Irren ist männlich.

Malo zbadana i słabo doceniona jest na dzień dzisiejszy istota internacjonalizmów paremiologicznych na zajęciach języka obcego i ich wkład w rozwój kompetencji językowej i interkulturowej. Nie- 
liczni badacze, a w jeszcze mniejszym stopniu praktycy doceniaja ich ogromny potencjał w rozwijaniu wielojęzyczności. W moim przekonaniu internacjonalizmy paremiologiczne sa jednak bardzo dobrym i efektywnym materialem pomocniczym w nauce kolejnych języków obcych, tym bardziej, iż - jak słusznie zauważył niemiecki glottodydaktyk Gerhard Neuner - na naukę kolejnych języków uczący się mają zwykle znacznie mniej czasu niż na naukę pierwszego języka obcego, stąd pożądane są wszelkiego rodzaju metody szybszego i ekonomiczniejszego uczenia się i nauczania (por. Neuner 2003: 31).

Internacjonalizmy paremiologiczne w nauczaniu języka obcego pomagają odkryć elementy własnej kultury w innych kulturach, co dziala motywująco na uczących się (por. Zenderowska-Korpus 2002: 103). Ponadto ich podobieństwa w wymiarze leksykalnym, morfologicznym i syntaktycznym wplywaja pozytywnie na proces zapamiętywania. Pamiętać przy tym należy, iż internacjonalizmy paremiologiczne wskutek swojej obrazowej natury i językowego podobieństwa wspierają rozwój kompetencji językowej i socjokulturowej więcej niż jednego języka obcego (por. Schatte 2006: 154). Co więcej praca $z$ nimi jest bardzo efektywną metodą zarówno nauki kolejnego języka obcego, jak i powtarzania i ugruntowywania wiedzy i umiejętności z zakresu znajomości pierwszego języka obcego.

W dodatku internacjonalizmy paremiologiczne, podobnie jak przysłowia nieinternacjonalne, mogą funkcjonować w trakcie zajęć dydaktycznych jako ćwiczenie rozluźniające (por. ZenderowskaKorpus 2002: 338) lub jako impuls do dyskusji, badź nawet wypracowania (Schatte 2008: 91f.). Moga być również wykorzystywane jako przyklady funkcjonowania określonych struktur gramatycznych czy leksykalnych. Zamiast wymyślać sztuczne przyklady można posłużyć się przyslowiami i w ten sposób bez zbędnego wysilku upiec dwie pieczenie na jednym ogniu - ucząc gramatyki i przyslów jednocześnie (por. Zenderowska-Korpus 2002: 343).

Jednak najważniejszą funkcją przysłów jest ich wkład w rozwój kompetencji interkulturowej. Przedstawiają one podobne dla wielu krajów i kultur obrazy świata, treści i obserwacje (por. Schatte 2008: 
92). Praca $z$ internacjonalizmami paremiologicznymi jest bardzo owocna, gdyż pozwala na odkrycie cech wspólnych między językiem i kulturą ojczystą a kilkoma innymi językami i kulturami, co znacznie poprawia wyobrażenie o tych krajach, jak również pomaga w lagodzeniu uprzedzeń i negatywnych stereotypów w odniesieniu do nich.

Warto również zwrócić uwagę, że stosowanie internacjonalizmów paremiologicznych w nauczaniu jest tym bardziej korzystne, iż wiele spośród zgromadzonych polskich, angielskich i niemieckich przysłów internacjonalnych należy do tzw. minimum przysłowiowych, a więc listy najpopularniejszych przysłów w celu ustalenia niezbędnego paremioleksykonu m.in. dla potrzeb dydaktyki języka jako obcego (por. Szpila 2002: 36). Przykladem jest przysłowie:

Gdzie kucharek szesśc, tam nie ma co jeść.

Too many cooks spoil the broth.

Viele Köche verderben den Brei.

\section{Podsumowanie}

Reasumując warto podkreślić ogromną rolę internacjonalizmów paremiologicznych w nauce języków obcych, a w szczególności języka drugiego i kolejnych. Przyslowia te przyśpieszaja proces przyswajania języka, ugruntowują umiejętności i wiedzę już nabyta. a także dzialają motywująco na uczących się. Ponadto pomagają budować mosty między różnymi kulturami, pozwalając dostrzec wspólne elementy dla wszystkich trzech języków i kultur. Przez to wplywaja pozytywnie na rozwój kompetencji interkulturowej. W kontekście wielojęzyczności przyśpieszają proces przyswajania przynajmniej dwóch języków obcych i rozwijają wiedzę w zakresie znajomości wlasnej kultury i tradycji.

Niniejszy artykul ma stanowić punkt wyjścia do dalszych analiz w tym kierunku, ponieważ do tej pory problem ten nie został wystarczajaco zbadany. Ponadto w kontekście materiałów dydaktycznych warto zastanowić się nad uwzględnieniem przyslów internacjonal- 
nych w podręcznikach do nauki języków obcych. Kolejny problem zwiazany z wprowadzeniem przyslów internacjonalnych do materialów dydaktycznych na zajęciach języka obcego, to odpowiednie uwrażliwienie nauczycieli. Nauczyciele znający tylko jeden język obcy nie będą w stanie wykorzystać ogromnego potencjalu przyslów internacjonalnych, stąd rodzi się potrzeba wymagania od kadry nauczającej znajomości drugiego języka obcego, przynajmniej w stopniu umożliwiajacym stosowanie internacjonalizmów leksykalnych, frazeologicznych i paremiologicznych na zajęciach języka obcego.

\section{Bibliografia}

Bartoszewicz, Iwona (1998): Deutsch-polnisches Sprichwōrterlexikon: eine repräsentative Auswahl. Heidelberg: J. Groos.

Burger, Harald (1998): Phraseologie. Eine Einführung am Beispiel des Deutschen. Berlin: E. Schmidt, cop.

Edmondson, Willis (2004): „Je pense (in three languages), done je suis (mehrsprachig)". [w:] Bausch, Karl-Richard/Königs, Frank G./Krumm, Hans-Jürgen.: Mehrsprachigkeit im Fokus: Arbeitspapiere der 24. Frühjahrskonferenz zur Erforschung des Fremdsprachenunterrichts. Tübingen: Narr, cop., 39-44.

Forum Biznesu ds. Wielojęzyczności (2008): Języki są ważne dla przedsiębiorstw. Przedsiębiorstwa osiągają lepsze wyniki dzięki znajomości języków. Zalecenia Forum Biznesu ds. Wielojęzyczności ustanowionego przezKomisję. http://ec.europa.eu/education/languages/ pdf/davignon_pl.pdf [26.04.2010].

Komisja Europejska (1995): White Paper on Education and Training. Teaching and learning. Toward the learning society. Bruksela. http:// ec.europa.eu/education/languages/pdf/doc409_en.pdf [26.04.2010]

Komisja Wspólnot Europejskich (2008): Komunikat Komisji do Parlamentu Europejskiego, Rady Europejskiego Komitetu EkonomicznoSpołecznego i Komitetu Regionów. Wielojęzyczność: atut dla Europy i wspólne zobowiązanie. Bruksela. http://ec.europa.eu/education/languages/pdf/com/2008_0566_pl.pdf [26.04.2010].

Lipczuk, Ryszard (1992): „Internacjonalizmy a 'falszywi przyjaciele thumacza"”. [w:]: Maćkiewicz, Jolanta / Siatkowski, Janusz: Kontakty 
języka polskiego z innymi jęzkkami na tle kontaktów kulturowych (= Język a kultura 7). Wroclaw: Wiedza o Kulturze, 135-144.

Mieder, Wolfgang/Röhrich, Lutz (1977): Sprichwort. Stuttgart: Metzler.

Mieder, Wolfgang (2004): Proverbs: a handbook. Westport: Greenwood Publishing Group.

Neuner, Gerhard (2003): „Mehrsprachigkeitskonzept und Tertiärsprachendidaktik“. [w:] Hufeisen, Britta, Neuner, Gerhard: Mehrsprachigkeitskonzept - Tertiärsprachen - Deutsch nach Englisch: European Centre of Foreign Languages. Strasbourg, 13-34.

Permjakov, Grigorij L'vovic (1979): From proverb to folk-tale: notes on the general theory of cliche. Moskau: Nauka.

PWN (2009): Slownik języka polskiego. Wersja elektroniczna.

Raupach, Manfred (2003): „Zwei- und Mehrsprachigkeit”. [w:] Bausch, Karl-Richard./Christ, Herbert: Handbuch Fremdsprachenunterricht. Tübingen: Francke, 470-475.

Umurova, Gulnas (2005): Was der Volksmund in einem Sprichwort verpackt....Moderne Aspekte des Sprichwortgebrauchs - anhand von Beispielen aus dem Internet. Bern: Lang, cop..

Schatte, Czeslawa (2006): ,Zu Interphraseologismen in der Mehrsprachigkeitsdidaktik“. Studia Germanica Gedanensia 14, 143-156.

Schatte, Czeslawa (2008): „Zum Sprichwort-Minimum im Unterricht Deutsch als Fremdsprache“. [w:] Myczko, Kazimiera/Skowronek, Barbara/Zabrocki, Wladyslaw: Perspektywy glottodydaktyki i jezzykoznowstwa. Tom jubileuszowy z okazji 70. urodzin Profesora Waldemara Pfeuffera. Poznań: Wydawnictwo Naukowe Uniwersytetu im. Adama Mickiewicza w Poznaniu, 91-105.

Szpila, Grzegorz (2002): „Minimum paremiologiczne języka polskiego badanie pilotażowe." Jezzyk Polski LXXXII/1, 36-42.

Zenderowska-Korpus, Grażyna (2002): Form und Funktion sprachlicher Schematismen und ihre Vermittlung im Unterricht Deutsch als Fremdsprache. Poznan. 